\title{
Stratigraphy of a Silt-cored Palsa, Atlin Region, British Columbia, Canada
}

\author{
MATTI SEPPÄLÄ'
}

\begin{abstract}
Palsas in the Fourth of July Creek valley, B.C., Canada are round- or oval-shaped single hummocks with cores of silty permafrost. Their height ranges from 0.5 to $3 \mathrm{~m}$. The top layer of the studied palsa is only $7 \mathrm{~cm}$ peat. In the frozen silt core are found segregated ice lenses up to $15 \mathrm{~cm}$ thick. The $0.006-0.02 \mathrm{~mm}$ size fraction of the core material of the palsa constitutes $55 \%$. Carbon fourteen datings of the organic material of two different layers in the core of the palsa gave 7470 \pm 180 and $7990 \pm 180$ years B.P. Special attention is given to the unusual sequence of dates obtained and to the pollen stratigraphy. The material is explained by redeposition by flood water into a pond and later uplifting by frost. No evidence of mixing of the original bottom sediments is found.
\end{abstract}

RÉSUMÉ. Les "palsas" rencontrés dans la vallée de Fourth of July Creek, B.C., Canada, sont de simples mamelons de forme arrondie ou ovale, dont le coeur de pergelisol* est silteux.

Leur taille va de 0.5 à 3 metres. Le marqueur choc de ce palsa est un banc de tourbe de seulement $7 \mathrm{cms}$ d'épaisseur. Des lentilles de glace isolées, d'épaisseur allant jusqu'à 15 centimetres, se recontrent dans le coeur du silt gelé.

La fraction granulometrique de 0,006 à $0,2 \mathrm{~mm}$ constitue $55 \%$ de la roche silteuse gelée. A partir de deux marqueurs differents du coeur de la carotte de ce pingo, une datation au carbone 14 sur la matiere organique a permis de trouver des ages de $7470 \pm 180$ années et $7990 \pm 180$ années.

Ce creneau inhabituei d'ages et la stratigraphie à base pollinique ont fait l'objet d'un soin special. La présence du matériel s'explique par redepot à la site d'une inondatation d'un étang et soulevement par le gel, plus tard. Il n'y a aucune evidence d'une pollution par les sédiments d'origine, déposés au fond.

*Permafrost

Traduit par Alain de Vendegies, Aquitaine Co. Canada Ltd.

\section{INTRODUCTION}

In 1971 the author had the opportunity to make observations upon mineral core palsas in the Fourth of July Creek valley $\left(59^{\circ} 51^{\prime} \mathrm{N}, 133^{\circ} 20^{\prime} \mathrm{W}\right)$ about 45 $\mathrm{km} \mathrm{NE}$ of Atlin village in northern British Columbia (Fig. 1).

The palsas studied in this paper have been mentioned earlier in the literature by Tallman $(1973,1975)$ and Miller \& Anderson (1974).

The inner structure of this type of permafrost phenomenon has been investigated earlier in Scandinavia by Svensson (1964), Wramner (1973), and Åhman (1976) but no publications have been found in North American literature. It is necessary to distinguish palsas from pingos described, e.g., by 


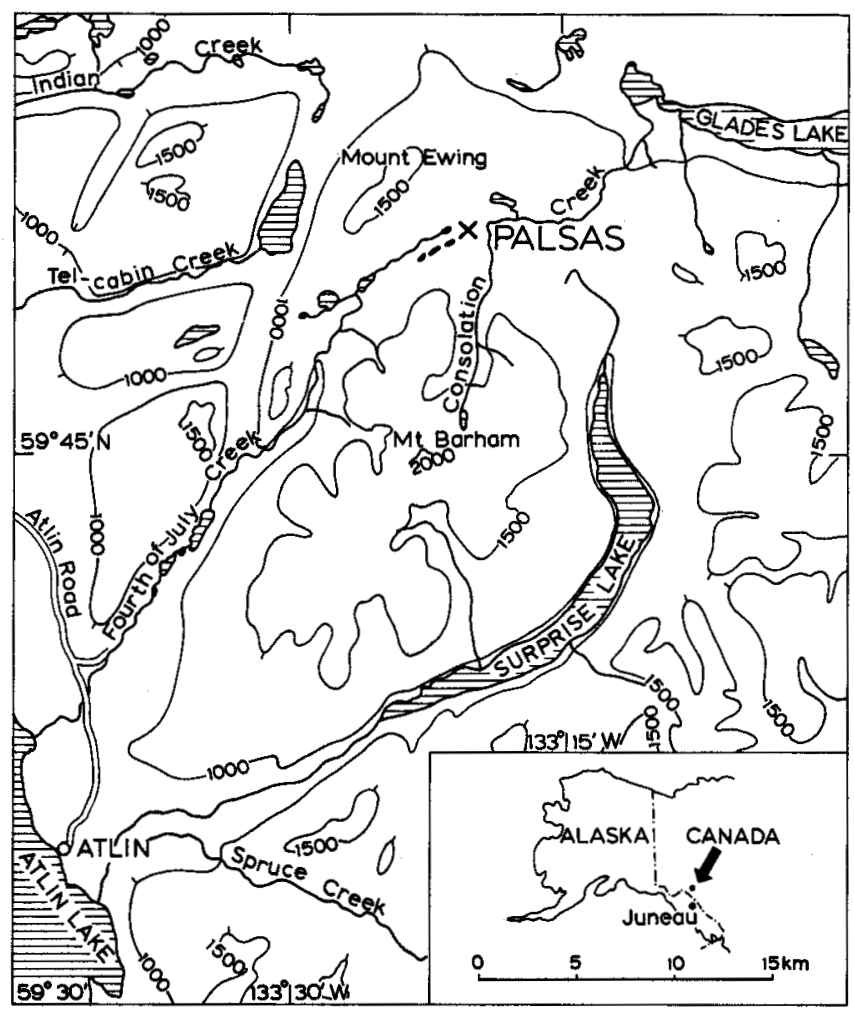

FIG. 1. General location of the palsa.

Mackay \& Stager (1966). Palsas are to be found in areas of sporadic or discontinuous permafrost where peat, with its excellent insulating properties, has preserved the frozen cores for several years (Seppälä, 1972).

\section{LOCATION AND CLIMATE}

The palsa bogs occur on the height of land between the Fourth of July Creek and Consolation Creek drainage basins (Fig. 1). In the middle of the Fourth of July Creek valley is an extremely large esker net landscape formed by late glacial melt waters. The studied palsas are about $1000 \mathrm{~m}$ a.s.1. on peat bogs in depressions between the eskers in a zone of sporadic permafrost (Brown, 1970). In this area continuous permafrost is found above $1600 \mathrm{~m}$ a.s.l. (Tallman, 1975).

During deglaciation a large ice-dammed lake formed in the valley, depositing at least $4.5 \mathrm{~m}$ of silty-clay lake sediments in places (Tallman, 1973; 1975). The minimum date for the plateau's deglaciation is $9315 \pm 540 \mathrm{C}-14$ years B.P. (Tallman, 1975.)

Records (1915-46) at the Atlin meteorological station $\left(59^{\circ} 35^{\prime} \mathrm{N}, 113^{\circ} 38^{\prime} \mathrm{W}\right)$ at $683 \mathrm{~m}$ altitude a.s.1. indicate that the mean annual temperature is approximately $0^{\circ} \mathrm{C}$ and total mean annual precipitation is approximately 280 


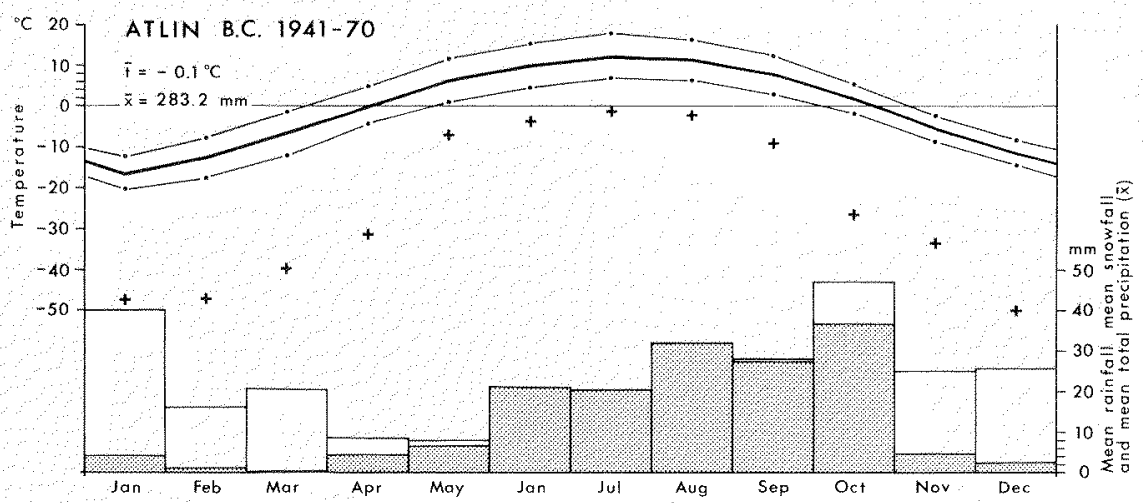

FIG. 2. Monthly mean rainfall (dark columns), mean snowfall (in $\mathrm{mm}$ of water) (white columns), mean total precipitation; daily mean, maximum, miminum and extreme minimum temperatures $(+)$ at Atlin, B.C., Canada in 1941-1970. (Source: Climate of British Columbia. Tables of temperature and precipitation. Climatic normals 1941-1970. British Columbia Department of Agriculture. Tables 1-3,5-8). Data converted into $\mathrm{mm}$ and ${ }^{\circ} \mathrm{C}$.

$\mathrm{mm}$, with approximately $135 \mathrm{~mm}$ of snowfall (Kendrew \& Kerr, 1955). More recent data from Atlin for the period 1941-70 are illustrated in Figure 2. These data are very similar to earlier records.

The palsas studied lie more than $300 \mathrm{~m}$ higher than the official meteorological station. The mean annual temperature at the palsa locality is therefore lower than at the station, presumably -2 or $-3^{\circ} \mathrm{C}$, which is normal in Scandinavia in the regions with palsas (Åmman, 1976; 1977).

The present timberline of the Atlin region lies at approximately $1200 \mathrm{~m}$ elevation (Tallman, 1975). White spruce forests with pine dominate at present.

\section{METHODS}

A pit, $1 \mathrm{~m}$ wide and $1.5 \mathrm{~m}$ deep, was dug into the edge of the palsa (Fig. 3). Visual observations were made in the field and some samples taken for laboratory analysis.

Grain size analyses of mineral material were carried out with a Sartorius 4600 sedimentation balance at the Department of Quaternary Geology, University of Turku, Finland.

Before $\mathrm{C}-14$ datings the samples were prepared by washing them with $\mathrm{NaOH}$ solution and $\mathrm{HCl}$ solution to loose soluble humus and $\mathrm{CaCO}_{3}$.

Pollen preparations of the silt samples were made with HF method.

\section{MORPHOLOGY OF PALSAS}

Palsas in the Fourth of July Creek valley are round- or oval-shaped single hummocks. The diameter of palsas ranges up to $100 \mathrm{~m}$ and their height from 0.5 to $3 \mathrm{~m}$ (Fig. 3). Shield-like low and flat palsas with a few spruce growing on them are the most typical forms. The frozen cores of some palsas have completely melted and only round ponds remain in their place, surrounded by 


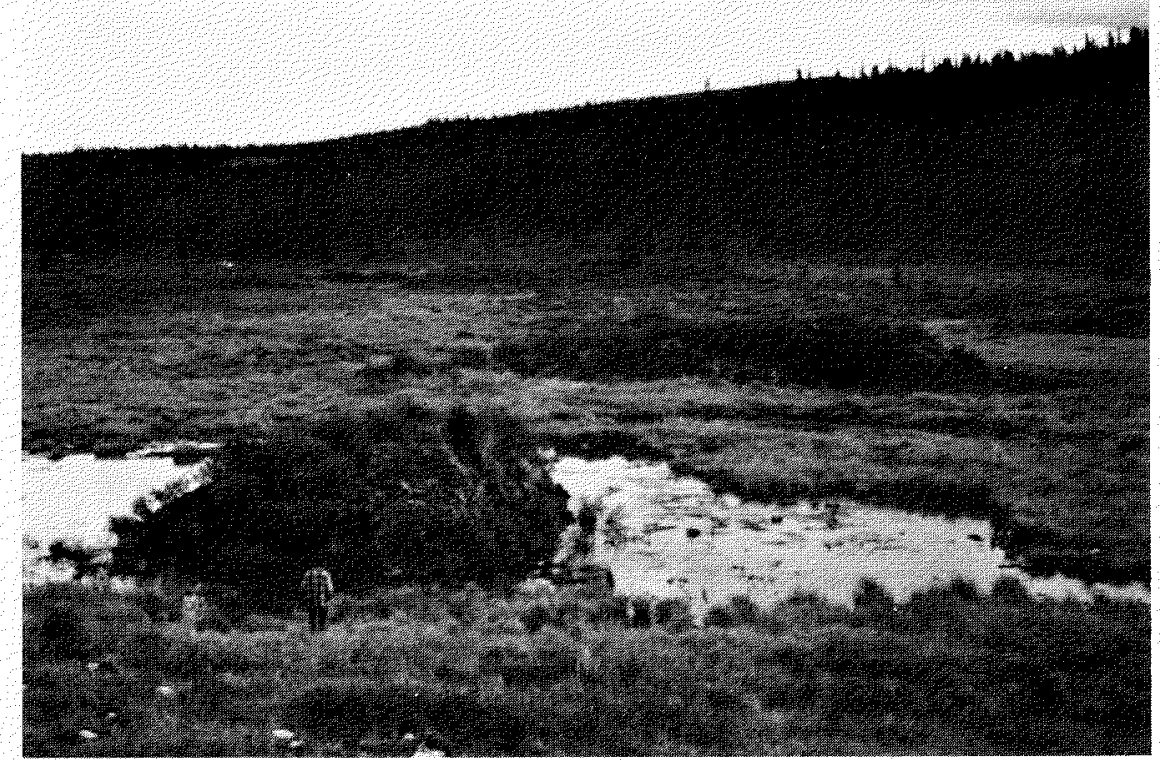

FIG. 3. The palsa studied in the watershed area between the Fourth of July Creek and Consolation Creek, B:C., 28th August, 1971. Photo by the author.

ridges approximately $0.5 \mathrm{~m}$ high. Good examples of growing palsas about 30 $\mathrm{cm}$ high and 5-6 $\mathrm{m}$ in diameter were found close to the collapsed forms. The collapsing forms were surrounded by a water body. Palsas in all stages of development were noticed, as reported by Zoltai (1972) elsewhere in North America.

\section{STRATIGRAPHY AND MATERIAL}

The stratigraphy is presented in Figure 4. The peat layer on the top of the palsa was surprisingly thin - about $7 \mathrm{~cm}$. Tallman (1973) has reported from the same region a thickness of $60 \mathrm{~cm}$ of peat on palsa surfaces and that the depth of the active layer varied from 30 to $75 \mathrm{~cm}$.

Dwarf birch and some willows grow on the palsa. The peat consists of poorly decomposed aquatic plants with woody material. Below the peat occurs silt with organic remnants. About $1 \mathrm{~m}$ below the surface a $6.5-\mathrm{cm}$ thick layer of clay-silt is found. Beneath this layer is a silt containing organic material, from which a radiocarbon date (Hel-231, Fig. 4, Table 1) and a pollen analysis were obtained. Another date was obtained from a lower silt layer containing organic material, from about $120 \mathrm{~cm}$ below the surface of the palsa (Hel-230, Fig. 4). These two dated layers were separated by about $8 \mathrm{~cm}$ of clay-silt containing no organic material. The material of this layer was analysed for grain size (Fig. 5). At a depth of $120 \mathrm{~cm}$ the frozen core of the palsa was found, containing a $15-\mathrm{cm}$ thick layer of segregated ice. The ice was clear with some air bubbles. Under the ice, frozen silt layers alternated with ice layers. In this region the depth of permafrost in palsas could reach 17-21 
TABLE 1. Results of pollen, spores and algae analyses of the two C-14 dated layers from the core of the palsa in Atlin region, B.C., Canada (Fig. 4). Analysed by Miss Liisa Ikonen.

AP

Alnus
Betula
Carpinus
Celtis
Corylus
Ostrya
Picea
Pinus
Tsuga

NAP

Artemisia

Cyperaceae

Graminae

Juniperus

Labiatae

Liliaceae

Ranunculaceae

Salix

Saxifraga aizoides

Szxifragaceae

Shepherdia canadensis

Sparganium

Viburnum

NAP Varia

Botrychium

Equisetum

Lycopodium

Polypodiaceae
Hel-230

$7470 \pm 180$ yrs. B.P.

38

56

1

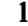

1

103

2

$\Sigma$ AP

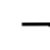

202
Hel-231

$7990 \pm 180$ yrs. B.P.

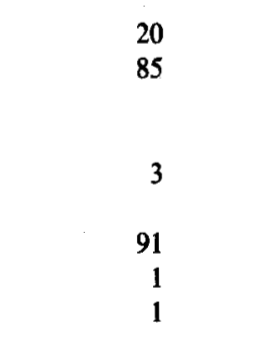

201

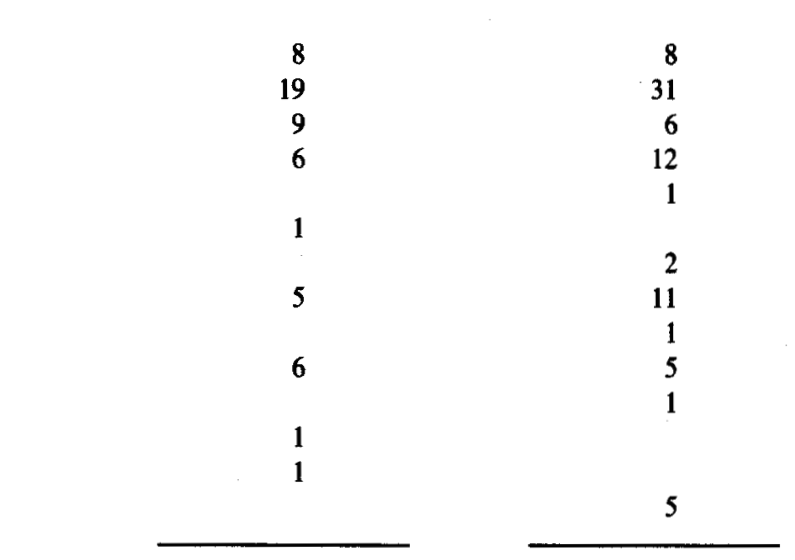

I NAP

56

83

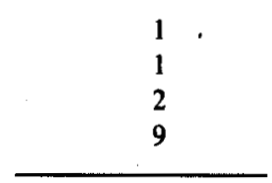

13

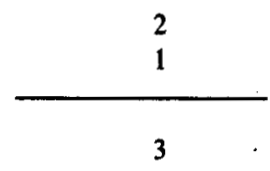




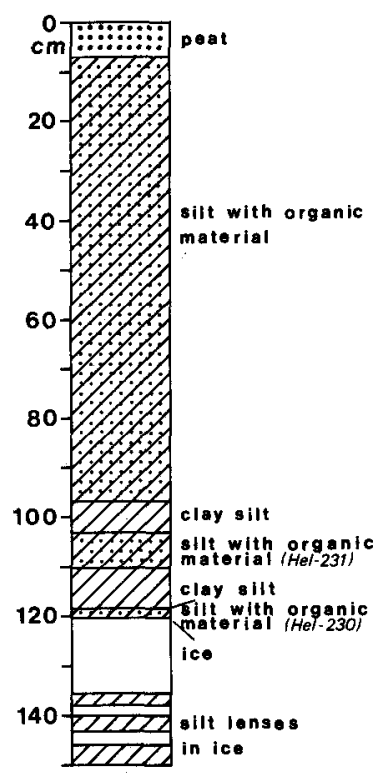

FIG. 4. Stratigraphy of the studied palsa. 28th August, 1971.

m, according to Tallman's (1973) observations upon the electrical resistivity of the ground.

The material of the palsa core in the Fourth of July Creek valley is $55 \%$ silt $(0.006-0.02 \mathrm{~mm}$ ). The amount of grains finer than 0.006 is $21 \%$ (Fig. 5) and the median is $0.009 \mathrm{~mm}$.

For comparison, one palsa core sample was analysed from Suttisjoki, Inari, Finland $\left(69^{\circ} 20^{\prime} \mathrm{N}, 26^{\circ} 43^{\prime} \mathrm{E}\right)$. The silt was somewhat coarser with the median at $0.022 \mathrm{~mm}$ and the amount of $0.006-0.02$ size fraction was $78 \%$ (Fig. 5). The form of the cumulative grain size curves of both samples is similar. The clay content (i.e. $<0.002 \mathrm{~mm}$ in diameter) of both samples is very low, being only a few percent.

In northern Norway the grain size distribution in the minerogenic core of palsas is normally a clayey silt. The clay content is between $5-30 \%$, and that of silt between $40-60 \%$. The main part of the soil is composed of particles with a grain size of 0.006-0.2 mm (Åhman, 1976). Soil with this grain size distribution has an intensive heaving capacity depending on water suction (Åhman, 1976).

Somewhat higher clay content in frozen mineral soil cores of palsas in Canada has been found by Zoltai (1972), ranging from 23 to $66 \%$ with the silt content between 32 and 62 per cent.

\section{RADIOCARBON DATINGS}

$\mathrm{C}-14$ datings of the organic material of two different layers in the core of the palsa indicate that the lower layer $(\mathrm{Hel}-230)$ is younger $(7470 \pm 180$ years B.P.) than the upper silt layer (Hel-231, $7990 \pm 180$ years B.P.). The dates do 


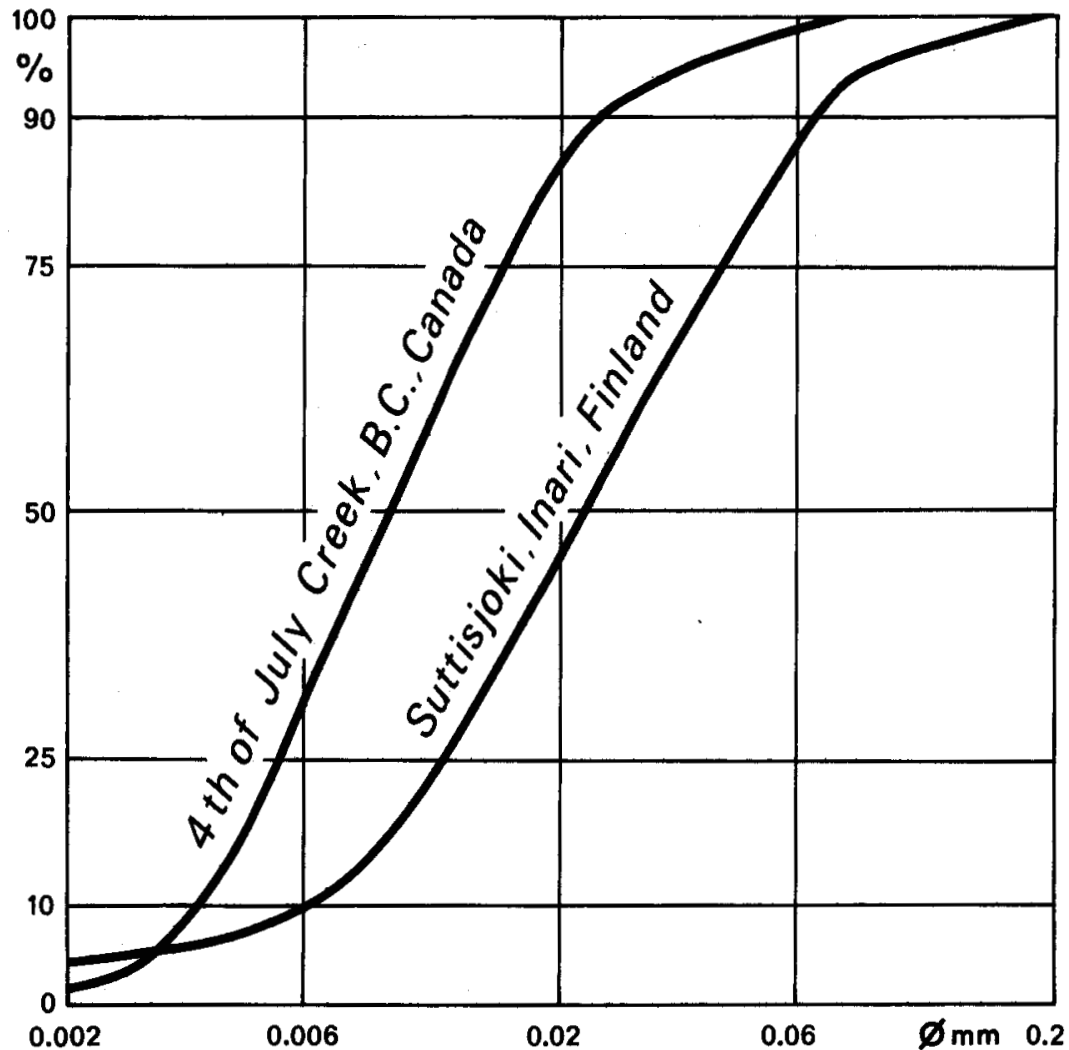

FIG. 5. Grain size composition of the silt core of the palsa compared with a palsa in Suttisjoki region, northernmost Finland (see Seppälä, 1971).

not indicate the age of the palsa but instead, the time of deposition of the sampled sediments.

One explanation for the fact that the lower layer is younger than the upper layer may be the re-deposition of older organic materials, by bank undercutting due to wave action and/or by high discharge of the streams draining into the pond.

The limitations of the use of lake deposits in radiocarbon datings because of contaminants, hard water effects and reservoir effects have been given by Donner \& Jungner (1974) and by Olsson(1979).

\section{POLLEN ANALYSES}

A relatively high content of birch (Betula) pollen (Table 1) indicates that the period was comparable to the pre-Boreal (dated from 9000 to 8000 years B.P.) (Anderson, 1970; Miller and Anderson, 1974). This is close to the time when the material of the sample (Hel-231) was deposited. The number of Betula pollen and NAP decreases, and the amount of Picea and Alnus pollen increases, when one moves to the younger deposits (sample Hel-230 in Table 1). 
It has been suggested that air temperatures and precipitation in the Atlin region were somewhat higher during the period 8000 to 5500 years B.P. (Anderson, 1970). This means that the region was semiarid, promoting widespread development of spruce-forest vegetation (Anderson, 1970; Miller \& Anderson, 1974). It was the Boreal phase in vegetation development.

The pollen analyses corroborate the idea that the two silty humic layers might have been redeposited from earlier sediment.

\section{DISCUSSION}

According to the stratigraphy of the palsa, the history of its development was as follows: glaciofluvial sedimentation of silt into a lake; postglacial sedimentation of silt in a pond, during which there was some redeposition of sediments with organic material; formation of aquatic peat in the pond; formation of frozen core of the palsa with uplift; and the growth of the present palsa.

Cryoturbation caused by frost has not disturbed the original stratification of the silt layers. No evidence of mixing of material in the palsa core was found. This means that normal palsa formation, where freezing occurs from the surface of the mire downwards, has formed these mounds. In the normal growth of pingos and hydrolaccoliths (Mackay, 1973), the original stratigraphy is completely disturbed and may be turned upside down. This is not the reason for the reversed order of layers in the core of the palsa.

\section{ACKNOWLEDGEMENTS}

Prof. M. M. Miller and the staff of the XI Summer Institute of Arctic and Alpine Research, Michigan State University, gave necessary help in the field and guided me to the study region. Miss Liisa Ikonen, Geological Survey of Finland, made the pollen analyses. Radiocarbon datings were made at the Radiocarbon Dating Laboratory of the University of Helsinki. Mrs. Anja Kaunisoja and Mrs. Iris Lampila made final drawings of the figures. Dr. H. M. French, Ottawa, helped to improve the English text.

Travel costs were supported by The National Council of Natural Science, Finland, The National Science Foundation. U.S.A., Leo and Regina Wainstein's Foundation, Finland, and The Foundation for Glacial and Environmental Research, Seattle, U.S.A.

\section{REFERENCES}

ÅHMAN, R. 1976. The structure and morphology of minerogenic palsas in northern Norway. Biuletyn Peryglacjalny 26:25-31.

1977. Palsar i Nordnorge. (Summary: Palsas in northern Norway). Meddelanden frăn Lunds Universitets Geografiska Institution, Avhandlingar 78:165 pp.

ANDERSON, J. H. 1970. A geobotanical study in the Atlin region in northwestern British Columbia and south-central Yukon Territory. Ph.D. thesis, Department of Botany and Plant Pathology, Michigan State University, East Lansing. 380 pp.

BROWN, R. J. E. 1970. Permafrost in Canada. University of Toronto Press. 234 pp.

CLIMATE OF BRITISH COLUMBIA. Tables of temperature and precipitation. Climatic normals 1941 - 1970. British Columbia Department of Agriculture.

DONNER, J. J. and JUNGNER, H. 1974. Errors in the radiocarbon dating of deposits in Finland from the time of deglaciation. Bulletin of The Geological Society of Finland 46:139-144. 
KENDREW, W. G. and KERR, D. 1955. The climate of British Columbia and the Yukon Territory. Ottawa: Edmond Cloutier. $222 \mathrm{pp}$.

MACKAY, J. R. 1973. The growth of pingos, Western Arctic Coast, Canada. Canadian Journal of Earth Sciences 10:979-1004.

and STAGER, J. K. 1966. The structure of some pingos in the Mackenzie Delta area, N.W.T. Geographical Bulletin 8:360-368.

MILLER, M. M. and ANDERSON, J. H. 1974. Pleistocene-Holocene sequences in the Alaska-Canada boundary range. Alaskan glacier commemorative project, phase IV. National Geographic Society Research Reports, 1967 Projects, Washington, D.C. 197-223.

OLSSON, I. U. 1979. A warning against radiocarbon dating of samples containing little carbon. Boreas 8:203-207.

SEPPÄLÄ, M. 1971. Evolution of eolian relief of the Kaamasjoki-Kiellajoki river basin, Finnish Lapland. Fennia 104:88 pp.

1972. The term "palsa". Zeitschrift für Geomorphologie N.F. 16:463.

SVENSSON, H. 1964. Structural observations in the minerogenic core of a pals. Svensk geografisk arsbok 40:138-142.

TALLMAN, A. M. 1973. Resistivity methodology for permafrost delineation. Research in Polar and Alpine Geomorphology. Fahey, B. D. and Thompson, R. D. (eds.). Department of Geography, University of Guelph. Geographical Publication 3:73-83.

1975. Glacial and periglacial geomorphology of the Fourth of July Creek valley, Atlin region, Cassiar District, northwestern British Columbia. Unpublished Ph.D. thesis, Michigan State University, $150 \mathrm{pp}$.

WRAMNER, P. 1973. Palsmyrar i Taavavuoma, Lappland. (Summary: Palsa bogs in Taavavuoma, Swedish Lapland). Göteborgs Universitet Naturgeografiska Institutionen, Rapport 3:140 pp.

ZOLTAI, S. C. 1972. Palsas and peat plateaus in Centreal Manitoba and Saskatchewan. Canadian Journal of Forest Research 2: 291-302. 